\title{
Poneromorph Ants Associated with Parasitoid Wasps of the Genus Kapala Cameron (Hymenoptera: Eucharitidae) in French Guiana
}

\author{
Jean-Paul Lachaud,, ${ }^{1,2}$ Philippe Cerdan, ${ }^{3}$ and Gabriela Pérez-Lachaud ${ }^{2}$ \\ ${ }^{1}$ Centre de Recherches sur la Cognition Animale, CNRS-UMR 5169, Université de Toulouse UPS, 118 Route de Narbonne, \\ 31062 Toulouse Cedex 09, France \\ ${ }^{2}$ El Colegio de la Frontera Sur, Entomología Tropical, Avenida Centenario km 5.5, Chetumal 77014, Quintana Roo, Mexico \\ ${ }^{3}$ Laboratoire Environnement de Petit Saut (HYDRECO), BP 823-97388 Kourou Cedex, France \\ Correspondence should be addressed to Jean-Paul Lachaud, jlachaud@ecosur.mx
}

Received 13 June 2011; Accepted 17 July 2011

Academic Editor: Jacques H. C. Delabie

Copyright (๑) 2012 Jean-Paul Lachaud et al. This is an open access article distributed under the Creative Commons Attribution License, which permits unrestricted use, distribution, and reproduction in any medium, provided the original work is properly cited.

\begin{abstract}
Eucharitid wasps are specific, specialized parasitoids of ants. The genus Kapala Cameron is the most common in the Neotropics but few species are described, and information dealing with their biology, behavior and host associations is scarce. Numerous poneromorph ant colonies were inspected over 4 collection surveys in French Guiana. A diverse fauna of parasites and parasitoids was found, including mermithid nematodes, flies, eucharitids, and another gregarious endoparasitoid wasp. Five new host associations for Kapala are reported, all of them involving medium- to large-size poneromorph ant species from 4 genera: Ectatomma brunneum Fr. Smith, Gnamptogenys tortuolosa (Fr. Smith), Odontomachus haematodus (L.), O. mayi Mann, and Pachycondyla verenae (Forel). Three other associations involving O. hastatus (Fabr.), P. apicalis (Latreille), and P. stigma (Fabr.), already reported for other countries but new for French Guiana, are confirmed. The data extend the number of hosts for Kapala to 24 ant species from 7 genera. The high diversity of the ant host genera associated with Kapala, combined with the fact that these ant genera are the most widely distributed among Neotropical poneromorph ants, could account for the dominant status of the genus Kapala among the eucharitine wasps of Central and South America.
\end{abstract}

\section{Introduction}

Within Hymenoptera, the family Eucharitidae (subdivided in three subfamilies: Oraseminae, Eucharitinae, and the IndoPacific Gollumiellinae) is the most numerous and diverse group of ant parasitoids $[1,2]$. All of the members of this family have a highly modified life cycle [3-6]. Unlike most parasitic wasp species, eucharitid females deposit their eggs away from hosts, in or on plant tissue [2, 7]. The active firstinstar larva, termed planidium, is responsible for gaining access to the host ant larvae by using various phoretic behaviors including either attachment to an intermediate host (most often a potential ant prey) or to foraging ant workers, with on occasion the presence of attractive substances in or on the eggs $[2,8]$. Within the nest, planidia attach themselves to ant larvae, but development is only completed when the host pupates $[6,7,9,10]$. In almost all of the cases, adults emerge among ant brood (but see [11]) and have to leave the host nest to reproduce. Ants show only moderate aggression to newly emerged eucharitids $[7,12-17]$ and transport them outside as if they were refuse $[11,15,17]$, ultimately enhancing wasp dispersal. Parasitism is very variable and localized in time and space $[13,18,19]$. A very high local prevalence may lead to only a very low impact at the regional scale, suggesting that these parasitoids do not have a major influence on the dynamics of their host population [19]. However, they constitute a remarkable example of both host-parasitoid coevolution and host behavior manipulation.

The eucharitine genus Kapala Cameron is widespread in the New World, with only one species, K. ivorensis Risbec, found in the Old World (Ethiopian region and Malagasy). This is one of the eucharitid genera most commonly collected by traps and aerial nets in the Neotropical region [1]. 
However, taxonomic and systematic studies of the species belonging to this genus have proved difficult because of the high degree of morphological variability both within and among species [20]. Only 17 species have been described up to now, but more than 60 are estimated to exist $[1,10]$. This genus is presently under revision (E. Murray and J. M. Heraty, pers. comm). Information dealing with the biology, ecology, and behavior of Kapala wasps is still very scarce (but see [10, 16, 18]), even though the number of known associations with ant hosts significantly increased in the past ten years. To date, all of the ant species which have been recorded as reliable hosts for the genus Kapala apply to medium to large poneromorph ant genera belonging to two subfamilies: Ponerinae and Ectatomminae [1, 4, 11, 21-24]. As all of the ant larvae attacked by Kapala pupate inside a protective cocoon, immature stages of the parasitoids are not easily spotted unless under close scrutiny. Furthermore, accurate host records can only be obtained by direct rearing of the parasitoids from ant brood and need laborious target sampling and collection. This could explain in part why so few associations have been reported before the late 90s. Here we both summarize the results of several collection surveys in French Guiana aimed to contribute to the knowledge of the diversity and distribution of the Kapala species in the Neotropics and provide a comprehensive review of ant-host associations for this highly variable genus.

\section{Materials and Methods}

Several dozen colonies (or portions of colonies) of poneromorph ants were collected in French Guiana, during 4 extensive surveys between 2002 and 2010. Collecting surveys were performed during both dry and rainy seasons and at several biotopes, mainly lowland rainforest fragments but also second growth vegetation. Ants were collected from several forest fragments along the road leading to the Hydroelectric complex at Petit Saut, Sinnamary $\left(5^{\circ} 03^{\prime} 39^{\prime \prime} \mathrm{N}\right.$; $\left.53^{\circ} 02^{\prime} 36^{\prime \prime} \mathrm{W}\right)$. Samples were obtained by systematically breaking up all of the fallen rotten logs found on the ground or were visually detected in the case of tree-inhabiting ants. Colonies of Ectatomma brunneum Fr. Smith were common in a ruderal area running along Route No. 1 from Kourou to Sinnamary (kilometric point 101) and were collected from the soil by excavation. Complete colonies or significant parts of colonies containing cocoons and larvae were taken to the laboratory. Most ants were identified to species level with available keys. Nest composition (presence and number of dealate females, alate females, males, workers, cocoons, and larvae), including the presence of adult eucharitids, was determined, and all of the pupae (cocoons) were dissected under a stereomicroscope and checked for the presence of eucharitids or for evidence of their attack. In particular, we looked both for wasp remains (exuvia) within empty ant cocoons denoting previous eucharitid emergence and for the presence of any abnormal pupa (phthisergate, phthisogyne, or phthisaner, according to the caste) indicating an unsuccessful eucharitid attack [12]. Larvae were also checked for the presence of planidia attached to their cuticle or for the presence of round melanized scars, an evidence of the previous attachment of a planidium [19]. Voucher specimens of ants were deposited in the Arthropod Collection at El Colegio de la Frontera Sur-Chetumal. Eucharitid specimens were sent to the specialist of this group, Dr. John M. Heraty (UCR).

\section{Results}

A total of 161 complete colonies of poneromorph ants or colony fragments with pupae, representing 26 species from 3 subfamilies, were collected and their contents examined (Table 1). No evidence of eucharitid attack to larvae was found for any of the poneromorph ant species examined, but several species of Kapala were found parasitizing the pupae of 8 different ant species. Of these, 5 represent new host associations (Table 1): one for the genus Ectatomma Fr. Smith (E. brunneum Fr. Smith), one for the genus Gnamptogenys Roger (G. tortuolosa (Fr. Smith)), and two for the genus Odontomachus Latreille (O. haematodus (L.), $O$. mayi Mann). The fifth new host record involves the genus Pachycondyla Fr. Smith and concerns a P. verenae (Forel) colony which was collected by Ronara de Souza Ferreira in the Southwestern part of French Guiana, at Camp Patawa, about $40 \mathrm{~km}$ from Roura in the direction of Raw. In addition, the host status of $O$. hastatus (Fabr.) - already reported for Ecuador [1] —and of P. stigma (Fabr.) and P. apicalis (Latreille)_already reported for Mexico [10, 22, 24]— were confirmed, and this constitutes the first report for French Guiana.

Due to the very reduced number of sampled nests for $O$. mayi and P. apicalis, percent parasitism figures (number of infested nests/number of revised nests) for these species are given only as indicative of eucharitid attack. For those species where a significant number of nests could be revised, prevalence of parasitism was generally low to medium (from $14.3 \%$ for P. stigma to $27.3 \%$ for G. tortuolosa) but reached up to $50 \%$ in the case of $O$. hastatus. However, parasitism rate within parasitized colonies was very low for all of the species, and only few eucharitid specimens were retrieved (Table 1).

Apart from eucharitids, some other parasites were found attacking ant colonies. Pupae of $P$. goeldii (Forel) were parasitized by a gregarious endoparasitoid wasp, and those of P. commutata (Roger) and Paraponera clavata (Fabr.) were parasitized by two gregarious dipteran species. Finally, a mermithized worker was found in a $P$. stigma colony, and this constitutes the first report of mermithid nematode parasitization for this species. In the absence of any postparasitic juvenile, the mermithid species identification was not possible. Voucher specimens of both the ants and the mermithid nematode were deposited in the authors' collection.

\section{Discussion}

A diverse fauna of parasites and parasitoids attacked the different poneromorph ant species present in French Guiana near Petit Saut, including nematodes, flies, a gregarious 
TAble 1: Poneromorph ants of French Guiana and parasitism by Kapala. Ant species revised ( $n=$ number of nests containing pupae), presence of eucharitid wasps, parasitism rate by eucharitids (in \%), and number and developmental stage of specimens of Eucharitidae retrieved (F: female; M: male; A: adult, damaged specimen; Lif: first-instar larva feeding on host; Lf: last-instar larva; Pht.: phthisergate; Ex.: presence of eucharitid exuvia within an empty cocoon).

\begin{tabular}{|c|c|}
\hline Ant species & Parasites and parasitoids \\
\hline \multicolumn{2}{|l|}{ Ectatomminae } \\
\hline Ectatomma brunneum $(n=46)$ & Kapala sp. (21.7\%): 7 F, 1 M, 1 A, 2 Lif, 1 Pht., 1 Ex. \\
\hline Gnamptogenys pleurodon $(n=5)$ & - \\
\hline Gnamptogenys tortuolosa $(n=11)$ & Kapala sp. (27.3\%): 1 F, 1 Lf, 1 Lif, 1 Pht. \\
\hline Gnamptogenys sp. $(n=1)$ & - \\
\hline \multicolumn{2}{|l|}{ Ponerinae } \\
\hline Anochetus sp. $1(n=1)$ & - \\
\hline Anochetus sp. $2(n=3)$ & - \\
\hline Centromyrmex sp. $(n=1)$ & - \\
\hline Hypoponera sp. $1(n=4)$ & - \\
\hline Hypoponera sp. $2(n=1)$ & - \\
\hline Leptogenys sp. $1(n=2)$ & - \\
\hline Leptogenys sp. $2(n=1)$ & - \\
\hline Odontomachus haematodus $(n=20)$ & Kapala sp. (15.0\%): 1 F, 3 M, 1 Pht. \\
\hline Odontomachus hastatus $(n=6)$ & Kapala sp. (50.0\%): 2 F, 1 M, 2 Lf, 1 Lif \\
\hline Odontomachus mayi $(n=2)$ & Kapala sp. (50.0\%): $1 \mathrm{~F}$ \\
\hline Odontomachus sp. $1(n=1)$ & - \\
\hline Pachycondyla apicalis $(n=2)$ & Kapala sp. (50.0\%): 1 F, 2 M, 1 Ex. \\
\hline Pachycondyla commutata $(n=2)$ & 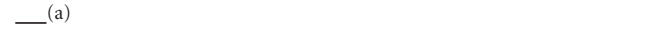 \\
\hline Pachycondyla constricta $(n=6)$ & - \\
\hline Pachycondyla crenata $(n=1)$ & - \\
\hline Pachycondyla goeldii $(n=2)$ & —(b) \\
\hline Pachycondyla harpax $(n=6)$ & - \\
\hline Pachycondyla obscuricornis $(n=3)$ & - \\
\hline Pachycondyla stigma $(n=21)$ & Kapala sp. $(14.3 \%)^{(\mathrm{c})}: 1 \mathrm{~F}, 1 \mathrm{M}, 1 \mathrm{Lif}$ \\
\hline Pachycondyla verenae $(n=6)$ & Kapala sp. $(16.7 \%): 1 \mathrm{M}$ \\
\hline Platythyrea sinuata $(n=6)$ & - \\
\hline \multicolumn{2}{|l|}{ Paraponerinae } \\
\hline Paraponera clavata $(n=1)$ & - (a) \\
\hline
\end{tabular}

(a) Presence of dipteran parasitoids;

(b) Presence of unidentified, gregarious parasitoid wasps;

(c) Presence of a mermithid nematode.

endoparasitoid wasp, and, above all, eucharitids. Several authors have recorded the presence of eucharitids in ant nests, but the information is scattered in the literature and concerns only few ant species. Neotropical eucharitine wasps are represented by approximately 160 species from 16 genera [1], but information on the host plant(s) used for oviposition is extremely scarce, and the identity of the ant host has been clearly established for only a few species belonging to 5 genera (Dilocantha Shipp, Isomerala Cameron, Kapala Cameron, Obeza Heraty, and Pseudochalcura Ashmead). These ant hosts concern exclusively formicine, ponerine, and ectatommine ants, whose larvae pupate inside a protective cocoon.

With about 60 estimated species, the genus Kapala is by far the most diverse and dominant eucharitine genus of Central and South America [1]. All of the hosts reported until now for this genus belong to 7 genera of ectatommine and ponerine ants (Table 2). Only K. floridana (Ashmead) has been reported associated with a host from another subfamily, the myrmicine ant Pogonomyrmex badius (Latreille) (according to Ashmead, in [12]), but, considering that Pogonomyrmex larvae do not spin a cocoon, such an association seems very doubtful $[1,10]$. Even if the presence of an undetermined species of eucharitid was already signaled for Gnamptogenys annulata (Mayr) and also for G. horni (Santschi) in Venezuela [26], and, very likely concerned a Kapala species, reliable associations between the genus Kapala and the ant genera Ectatomma and Gnamptogenys have previously been reported only for Mexico [10, 22] and for Colombia [25]. The new associations with these two ectatommine genera reported here for French Guiana, as well as the new associations or confirmations of record for the ponerine genera Odontomachus and Pachycondyla, support the outstanding importance of these four genera 
TABLE 2: Known ant host species associated with the eucharitid genus Kapala.

\begin{tabular}{|c|c|}
\hline Host species & Associated Kapala species \\
\hline \multicolumn{2}{|l|}{ Ectatomminae } \\
\hline \multicolumn{2}{|l|}{ Ectatomma Fr. Smith } \\
\hline E. brunneum Fr. Smith & Kapala sp. [this work] \\
\hline E. ruidum Roger & K. iridicolor (Cameron) $[10,18,25],[16,22]^{*}, K$. izapa Carmichael $[10,18]$ \\
\hline E. tuberculatum (Olivier) & Kapala sp. $[23]$ \\
\hline \multicolumn{2}{|l|}{ Gnamptogenys Roger } \\
\hline G. regularis Mayr & K. iridicolor (Cameron) $[10],[22]^{* *}$ \\
\hline G. striatula Mayr & K. iridicolor (Cameron) $[10],[22]^{* *}$ \\
\hline G. sulcata (Fr. Smith) & K. iridicolor (Cameron) [10], [22]**, Kapala sp. [24] \\
\hline G. tortuolosa (Fr. Smith) & Kapala sp. [this work] \\
\hline \multicolumn{2}{|l|}{ Typhlomyrmex Mayr } \\
\hline T. rogenhoferi Mayr & Kapala sp. [24] \\
\hline \multicolumn{2}{|l|}{ Ponerinae } \\
\hline \multicolumn{2}{|l|}{ Dinoponera Roger } \\
\hline D. lucida Emery & Kapala sp. [11] \\
\hline \multicolumn{2}{|l|}{ Hypoponera Santschi } \\
\hline H. nitidula (Emery) & Kapala sp. [24] \\
\hline \multicolumn{2}{|l|}{ Odontomachus Latreille } \\
\hline O. bauri Emery & Kapala sp. [1] \\
\hline O. brunneus (Patton) & Kapala sp. $[10,22]$ \\
\hline O. haematodus (L.) & Kapala sp. [this work] \\
\hline O. hastatus (Fabr.) & Kapala sp. [1], [this work] \\
\hline O. insularis Guérin-Méneville & K. terminalis Ashmead [4] \\
\hline O. laticeps Roger & Kapala sp. $[10,22,24]$ \\
\hline O. mayi Mann & Kapala sp. [this work] \\
\hline O. meinerti Forel & Kapala sp. [24] \\
\hline O. opaciventris Forel & Kapala sp. $[10,22]$ \\
\hline \multicolumn{2}{|l|}{ Pachycondyla Fr. Smith } \\
\hline P. apicalis (Latreille) & Kapala sp. $[22,24]$, this work] \\
\hline P. crassinoda (Latreille) & K. cuprea Cameron $[21]$ \\
\hline P. harpax (Fabr.) & K. atrata (Walker) $[1]^{* * *}$, Kapala sp. $[24]$ \\
\hline P. stigma (Fabr.) & K. iridicolor (Cameron) [10], [22]**, Kapala sp. [24], [this work] \\
\hline P. verenae (Forel) & Kapala sp. [this work] \\
\hline \multicolumn{2}{|l|}{ Myrmicinae } \\
\hline \multicolumn{2}{|l|}{ Pogonomyrmex Mayr } \\
\hline P. badius (Latreille) & K. floridana (Ashmead) [12] (doubtful record) $[1,10]$ \\
\hline
\end{tabular}

* Referred to as Kapala sulcifacies;

** Referred to as Kapala sp.;

*** Referred to as Kapala surgens.

of medium- to large-size poneromorph ants as potential hosts for Kapala wasps, a hypothesis previously formulated on the basis of more limited data $[10,22]$. In contrast with other eucharitid genera which have a limited range of potential hosts and a marked specificity towards the host as far as genus is concerned [4-6], the diversity of host genera and species attacked by Kapala is impressive. The data reported here for French Guiana extend the number of reliable host species for Kapala to 24 (see Table 2), a diversity of host species only comparable to that found for the worldwide distributed orasemine genus Orasema Cameron $[1,6]$. Such a broad range of potential hosts for Kapala is also observed at the species level. For example, K. iridicolor (Cameron) (Table 2) parasitizes no less than five different species from three genera and two ant subfamilies [10, 22], and a similar phenomenon is likely to concern also some of the other species reported here as undescribed under the label "Kapala sp." Furthermore, Kapala species are known to parasitize ants in very diverse habitats including both highly anthropic modified environments (roadsides, college campus, agroecosystems, pastures) and well-preserved forests $[1,10,22,24,25]$, [this work]. Combined with the fact that Ectatomma, Gnamptogenys, Odontomachus, and Pachycondyla are probably the four most widely distributed 
genera among the Neotropical poneromorph ants [27-29], the wide host range of Kapala species and their ability to attack ants in diverse habitats could account, at least in part, for the dominant status of this genus among the eucharitine wasps of Central and South America. Moreover, though the sampling of ant nests in general is not really adequate to confidently discuss rates of parasitism, for four species $(E$. brunneum, G. tortuolosa, O. haematodus, and P. stigma), the number of collected nests is significant enough (see $[18,19]$ for a comparison) to give a good idea of the rates of parasitism at the population level. The rate of parasitism is low to medium (from $14.3 \%$ to $27.3 \%$, see Table 1 ) in all of these four cases, but for certain associations, parasitism rate can reach significant values. Half of the nests were parasitized in the case of the association Kapala sp. and O. hastatus in French Guiana [this work] (but our sample limitationonly 6 nests-could result, in this specific case, in rates of parasitism relatively far from the natural figures) and up to $63 \%$ of the nests for the association between $K$. iridicolor $/ K$. izapa (Carmichael) and E. ruidum Roger in Mexico [18]. Such high parasitism rates certainly contribute to explain why Kapala is one of the eucharitid genera most commonly collected by traps and aerial nets in the Neotropical region [1].

All of the eucharitids are parasitoids of ants, but the exact relationship between these wasps and their host is far from being understood, and the scenario might be more complicated than once thought. For example, from the 17 species already described in the genus Kapala, the complete life cycle is known for only one of them, $K$. iridicolor [10]. However, even for this species, the way planidia manage to enter ant nests is unknown. Instead of a direct attachment to a foraging ant worker, some Kapala planidia have been recently reported attached to different species of scorpions, suggesting the use of alternative phoretic transport [30]. However, such occasional phoretic attachments to scorpions more likely correspond to random attachment to any nearby living object and likely have nothing to do with getting into the ant nest. They would just give evidence in favour of the high mobility of the planidia. Eucharitids are known to attack five subfamilies of ants, and a correlation between the phylogenetic relationships of the parasitoid and host is suggested by both morphological and molecular evidence ([1], E. Murray and J. M. Heraty unpubl. data). Additional information about ant hosts and within-nest biology as well as about oviposition habits throughout the geographical range of Kapala is critical for further resolving the limits and phylogenetic relationships of the species of this genus.

\section{Acknowledgments}

The authors thank all the team of the Laboratoire Environnement de Petit Saut (HYDRECO) for logistical help and for assistance with local accommodation. They also thank Alain Dejean and Jérôme Orivel (ECOFOG, French Guiana) for their help in ant identification and Sandor Buys and an anonymous refeere for helpful advices and useful suggestions on the paper. Ronara de Souza Ferreira kindly provided material from $P$. verenae. This research was partially supported by a grant from the French Ministère de l'Écologie et du Développement Durable (Program "Recherche de procédés limitant l'activité de fourmis tropicales d'importance écologique et économique"). The experiments comply with the current laws of the country in which they were performed.

\section{References}

[1] J. M. Heraty, "A revision of the genera of Eucharitidae (Hymenoptera: Chalcidoidea) of the World," Memoirs of the American Entomological Institute, vol. 68, pp. 1-367, 2002.

[2] J. M. Heraty, D. Hawks, J. S. Kostecki, and A. Carmichael, "Phylogeny and behaviour of the Gollumiellinae, a new subfamily of the ant-parasitic Eucharitidae (Hymenoptera: Chalcidoidea)," Systematic Entomology, vol. 29, no. 4, pp. 544559, 2004.

[3] C. P. Clausen, "The biology of Schizaspidia tenuicornis Ashm., a eucharid parasite of Camponotus," Annals of the Entomological Society of America, vol. 16, pp. 195-217, 1923.

[4] C. P. Clausen, "The habits of the Eucharidae," Psyche, vol. 48, pp. 57-69, 1941.

[5] G. C. Wheeler and E. W. Wheeler, "New hymenopterous parasites of ants (Chalcidoidea: Eucharidae)," Annals of the Entomological Society of America, vol. 30, pp. 163-175, 1937.

[6] J. M. Heraty, "Classification and evolution of the Oraseminae in the Old World, with revisions of two closely related genera of Eucharitinae (Hymenoptera: Eucharitidae)," Life Sciences Contributions, Royal Ontario Museum, vol. 157, pp. 1-176, 1994.

[7] C. P. Clausen, "The oviposition habits of the Eucharidae (Hymenoptera)," Journal of the Washington Academy of Sciences, vol. 30, pp. 504-516, 1940.

[8] J. M. Heraty and K. N. Barber, "Biology of Obeza floridana (Ashmead) and Pseudochalcura gibbosa (Provancher) (Hymenoptera: Eucharitidae)," Proceedings of the Entomological Society of Washington, vol. 92, pp. 248-258, 1990.

[9] J. M. Heraty, "Phylogenetic relationships of Oraseminae (Hymenoptera: Eucharitidae)," Annals of the Entomological Society of America, vol. 93, no. 3, pp. 374-390, 2000.

[10] G. Pérez-Lachaud, J. M. Heraty, A. Carmichael, and J.-P. Lachaud, "Biology and behavior of Kapala (Hymenoptera: Eucharitidae) attacking Ectatomma, Gnamptogenys, and Pachycondyla (Formicidae: Ectatomminae and Ponerinae) in Chiapas, Mexico," Annals of the Entomological Society of America, vol. 99, no. 3, pp. 567-576, 2006.

[11] S. C. Buys, R. Cassaro, and D. Salomon, "Biological observations on Kapala Cameron 1884 (Hymenoptera Eucharitidae) in parasitic association with Dinoponera lucida Emery 1901 (Hymenoptera Formicidae) in Brazil," Tropical Zoology, vol. 23, no. 1, pp. 29-34, 2010.

[12] W. M. Wheeler, "The polymorphism of ants, with an account of some singular abnormalities due to parasitism," Bulletin of the American Museum of Natural History, vol. 23, pp. 1-93, 1907.

[13] G. L. Ayre, "Pseudometagea schwarzii (Ashm.) (Eucharitidae: Hymenoptera), a parasite of Lasius neoniger Emery (Formicidae: Hymenoptera)," The Canadian Journal of Zoology, vol. 40, pp. 157-164, 1962.

[14] R. K. Vander Meer, D. P. Jouvenaz, and D. P. Wojcik, "Chemical mimicry in a parasitoid (Hymenoptera: Eucharitidae) of 
fire ants (Hymenoptera: Formicidae)," Journal of Chemical Ecology, vol. 15, no. 8, pp. 2247-2261, 1989.

[15] J.-P. Lachaud, G. Pérez-Lachaud, and J. M. Heraty, "Parasites associated with the ponerine ant Ectatomma tuberculatum (Hymenoptera: Formicidae): first host record for the genus Dilocantha (Hymenoptera: Eucharitidae)," The Florida Entomologist, vol. 81, no. 4, pp. 570-574, 1998.

[16] R. W. Howard, G. Pérez-Lachaud, and J.-P. Lachaud, "Cuticular hydrocarbons of Kapala sulcifacies (Hymenoptera: Eucharitidae) and its host, the ponerine ant Ectatomma ruidum (Hymenoptera: Formicidae)," Annals of the Entomological Society of America, vol. 94, no. 5, pp. 707-716, 2001.

[17] G. Pérez-Lachaud and J.-P. Lachaud, "Comportement de transport de parasitoïdes Eucharitidae par leur hôte: mimétisme chimique et effet de la taille de l'objet à transporter," in Proceedings of the Colloque Annuel de la Section Française de l'UIEIS, p. 32, Toulouse, France, 2007.

[18] J.-P. Lachaud and G. Pérez-Lachaud, "Impact of natural parasitism by two eucharitid wasps on a potential biocontrol agent ant in southeastern Mexico," Biological Control, vol. 48, no. 1, pp. 92-99, 2009.

[19] G. Pérez-Lachaud, J. A. López-Méndez, G. Beugnon, P. Winterton, and J.-P. Lachaud, "High prevalence but relatively low impact of two eucharitid parasitoids attacking the Neotropical ant Ectatomma tuberculatum (Olivier)," Biological Control, vol. 52, no. 2, pp. 131-139, 2010.

[20] J. M. Heraty and J. B. Woolley, "Separate species or polymorphism: a recurring problem in Kapala (Hymenoptera: Eucharitidae)," Annals of the Entomological Society of America, vol. 86, pp. 517-531, 1993.

[21] J. G. Myers, "Descriptions and records of parasitic Hymenoptera from British Guiana and the West Indies," Bulletin of Entomological Research, vol. 22, pp. 267-277, 1931.

[22] J.-P. Lachaud and G. Pérez-Lachaud, "Fourmis ponérines associées aux parasitoïdes du genre Kapala Cameron (Hymenoptera, Eucharitidae)," Actes des Colloques Insectes Sociaux, vol. 14, pp. 101-105, 2001.

[23] G. Pérez-Lachaud, J. A. López-Méndez, and J.-P. Lachaud, "Eucharitid parasitism of the Neotropical ant Ectatomma tuberculatum: parasitoid co-occurrence, seasonal variation, and multiparasitism," Biotropica, vol. 38, pp. 574-576, 2006.

[24] A. De la Mora and S. M. Philpott, "Wood-nesting ants and their parasites in forests and coffee agroecosystems," Environmental Entomology, vol. 39, no. 5, pp. 1473-1481, 2010.

[25] A. A. Vásquez Ordóñez, Parasitismo de Kapala iridicolor (Hymenoptera: Eucharitidae) sobre Ectatomma ruidum (Hymenoptera: Formicidae) en el Campus Meléndez de la Universidad del Valle, Cali, Colombia, Tesis de Licenciatura, Universidad del Valle, Santiago de Cali, Colombia, 2010.

[26] J. E. Lattke, "Revisión del género Gnamptogenys Roger en Venezuela," Acta Terramaris, vol. 2, pp. 1-47, 1990.

[27] B. Hölldobler and E. O. Wilson, The Ants, Springer, Berlin, Germany, 1990.

[28] B. Bolton, Identification Guide to the Ant Genera of the World, Harvard University Press, Cambridge, Mass, USA, 1994.

[29] B. Bolton, "Synopsis and classification of Formicidae," Memoirs of the American Entomological Institute, vol. 71, pp. 1-370, 2003.

[30] L. F. de Armas, "Identity of planidium larvae (Hymenoptera: Chalcidoidea) previously recorded on Antillean scorpions," Euscorpius, vol. 66, pp. 1-3, 2008. 

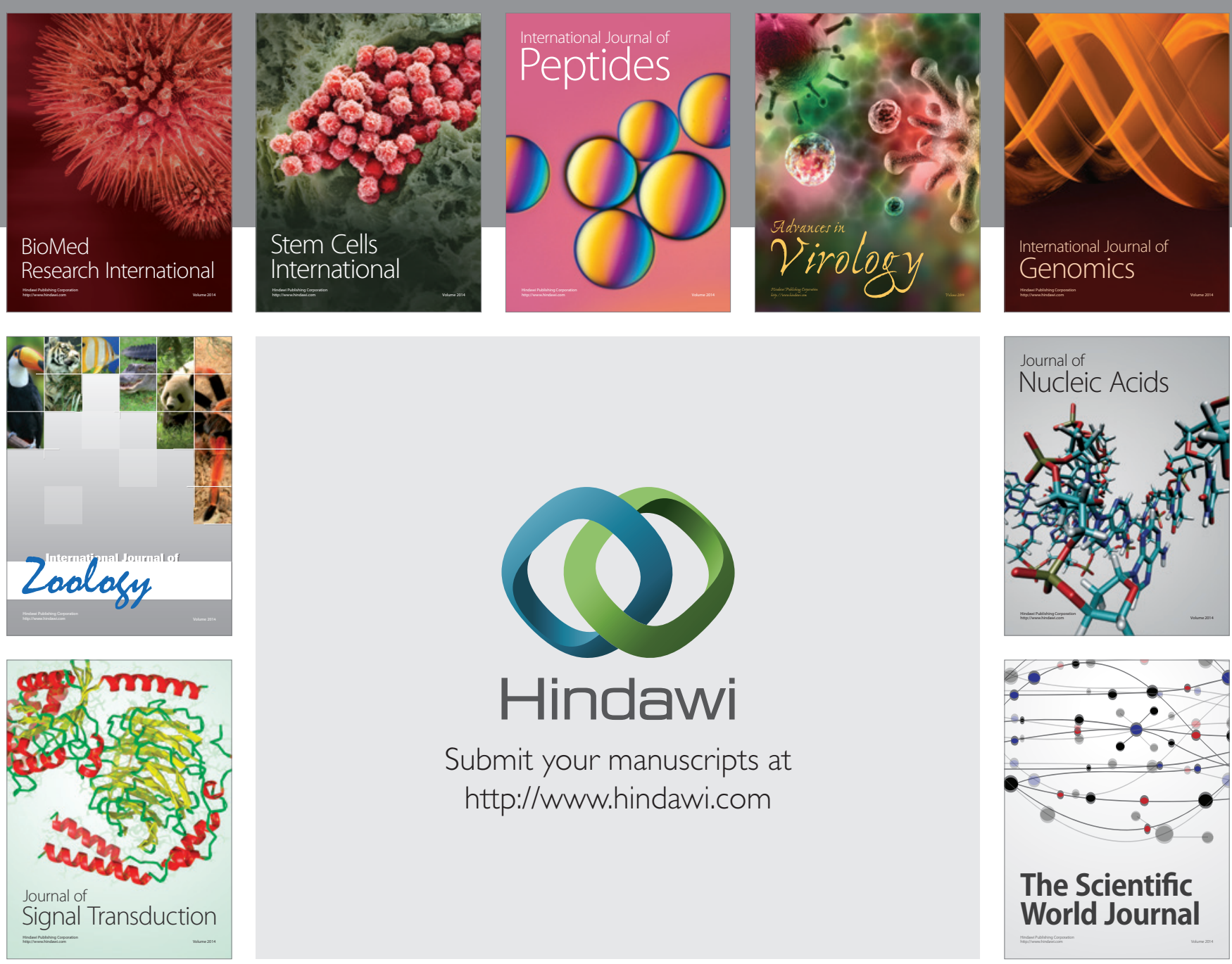

Submit your manuscripts at

http://www.hindawi.com
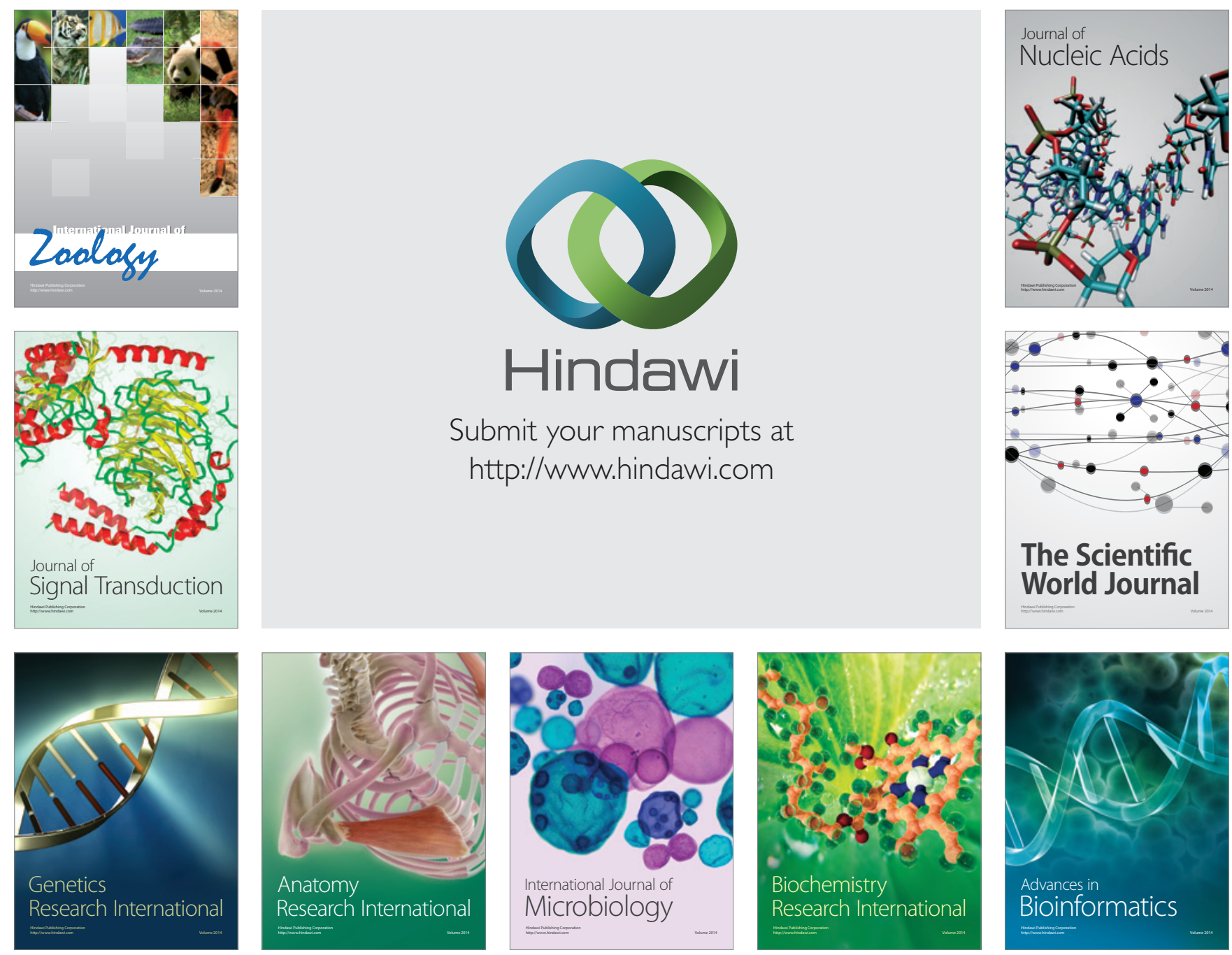

The Scientific World Journal
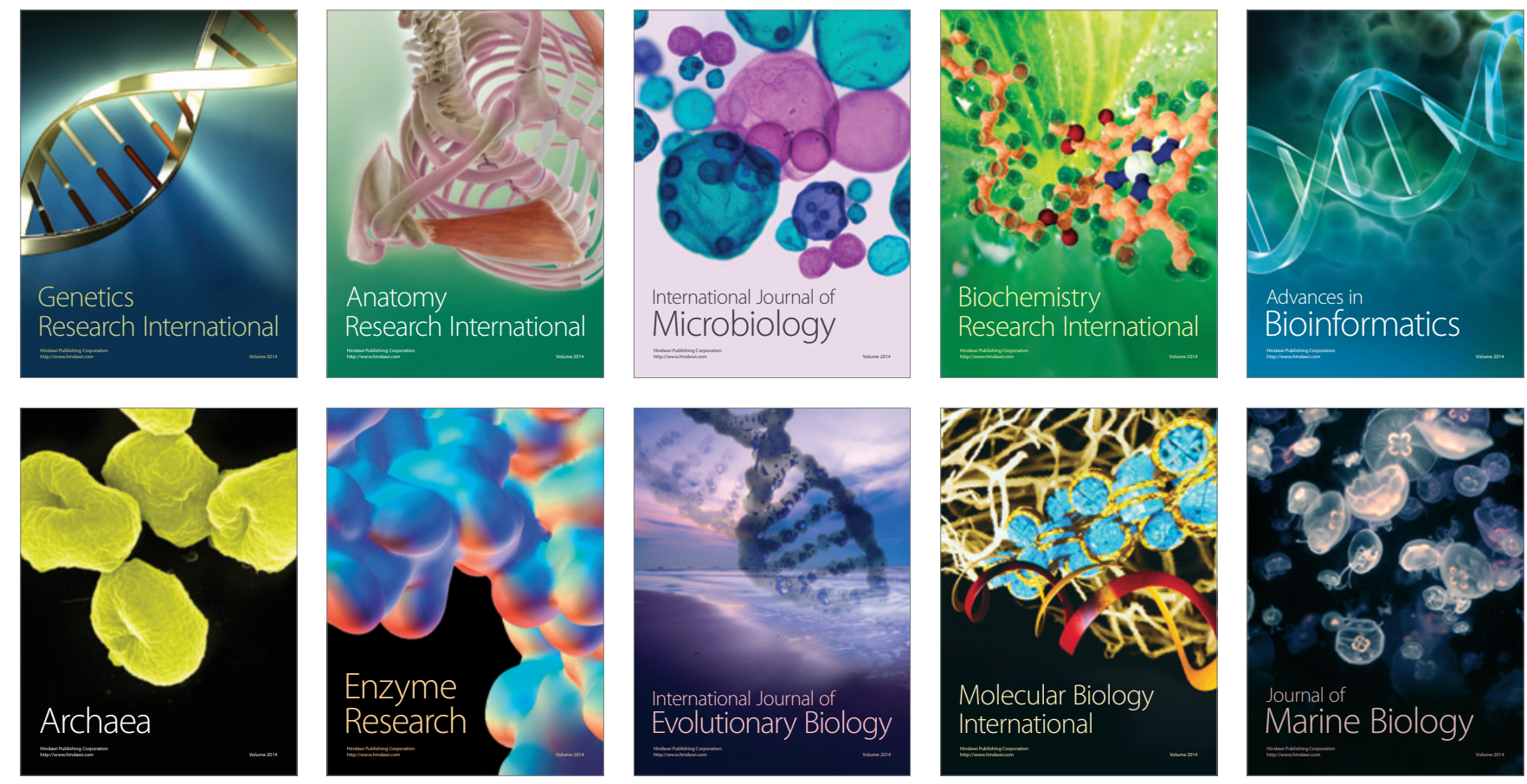